Ann. Biol. anim. Bioch. Biophys., I975, 15 (2), 30r-302.

\title{
SYNCHRONIZATION OF OESTRUS IN COWS USING INTRAVAGINAL SILASTIC COILS CONTAINING PROGESTERONE
}

\author{
J. F. ROCHE \\ The Agricultural Institute, Grange, Dunsany, \\ Co. Meath (Ireland)
}

Progesterone, given by silastic implant or pessary for 18 or 20 days will synchronize oestrus but fertility to AI at the controlled heat is lower than normal (SREENAN, I 972 ; ROCHE, I 974 a). Reducing the period of administration of progesterone down to ro days by giving an injection of $5 \mathrm{mg}$ oestradiol benzoate at time of insertion of implants, increased fertility but less heifers showed a synchronized heat (Roche, I $974 \mathrm{~b}$ ). Injecting $50 \mathrm{mg}$ of progesterone with the $5 \mathrm{mg}$ oestradiol benzoate given at time of insertion of implants increased the oestrous response to a Io-day progesterone treatment without affecting fertility (Roche, I974 b). To facilitate large scale farm trials, intravaginal silastic coils consisting of stainless steel strips coated in silastic rubber were impregnated with progesterone. Both retention rate and synchronizing efficiency were high.

Farm trials were conducted using silastic coils for I2 days with an injection of $5 \mathrm{mg}$ oestradiol benzoate and $50 \mathrm{mg}$ progesterone given at time of insertion of coils. Of 367 Friesian dairy cows treated, coils were retained in 340 . Of these 340 cows, 3 Io were observed in oestrus 2 to 6 days post-removal of the coils and were inseminated once with frozen semen. Fertility, based on pregnancy diagnosis or on $\mathbf{I}_{50} \mathrm{O}$-day non-return rates, was not different between treated and similar control cows in the same herds.

Injecting Ioo $\mu \mathrm{g}$ GnRH (Abbott Labs) 30 hours after removal of the silastic coils following the I2-day progesterone treatment resulted in $66 \mathrm{p}$. Ioo of animals ovulating 30 hours post $\mathrm{GnRH}$ while $90 \mathrm{p}$. Ioo had ovulated at 35 hours post GnRH. Fertility, following a fixed time insemination at 48 hours with $\mathrm{GnRH}$ or at $5^{6}$ and 74 hours without $\mathrm{GnRH}$ is not significantly different from controls. Thus, it appears that silastic coils impregnated with progesterone and inserted for I2 days with the oestrogen-progesterone injection given at time of insertion, give high synchronization rate, result in normal fertility and will allow animals to be inseminated on a fixed time basis with or without $\mathrm{GnRH}$.

Colloque: Control of sexual cycles in domestic animals October 27-30, 1974, Nouzilly. 


\section{RÉSUMÉ}

\section{SYNCHRONISATION DE L'GESTRUS CHEZ IA VACHE}

\section{GRACE A UN SERPENTIN DE SILASTIQUE CONTENANT DE LA PROGESTÉRONE}

Sur 340 vaches, on a obtenu une fertilité normale et une bonne synchronisation des œstrus (9I p. Ioo en 4 jours), en injectant $5 \mathrm{mg}$ de benzoate d'estradiol et $50 \mathrm{mg}$ de progestérone le jour de la mise en place vaginale d'un serpentin de silastique imprégné de progestérone qu'on retire I 2 jours plus tard.

\section{REFERENCES}

Roche J. F., r974a. Synchronization of cestrus in heifers with implants of progesterone. J. Reprod. Fert., 41, 337-344.

Rосне J. F, r974 $b$. Effect of short-term progesterone treatment on oestrous response and fertility in heifers. J. Reprod. Fert., 40, 433-440.

SREenan J., 1972. Induction and synchronization of oestrus in hill suckler cows. Res. Rep., 1972, p. I62. Anim. Prod. An Foras Taluntais. 